\title{
Optimal Peyzaj Uygunluk Analizi Yöntemi: Anamur İlçesi Örneği
}

\author{
Landscape Optimal Suitability Analysis Method: The Case of Anamur District
}

\author{
Tülay ERBESLER AYAȘLIGIL
}

ÖZ

Gerek dünyada gerek Türkiye'de, artan nüfus ve yaşamsal gereksinimler nedeniyle, doğal kaynakların en uygun kullanım şeklinin belirlenmesini gerektirmektedir. Sürdürülebilir kalkınma doğru arazi kullanım kararlarının alınmasına bağlıdır. Toprak yapısının sahip olduğu üretim yeteneği o arazinin biyokütle performansını belirler. Bu araştırmada tarım, orman, çayır ve mera olmak üzere bu üç kullanım türüne göre Anamur İlçesi topraklarının en uygun arazi kullanım biçiminin belirlenmesi amaçlanmıştır. Coğrafi Bilgi Sistemleri (CBS) destekli Optimal Peyzaj Uygunluk Analizi Yöntemi (LANDEP) uygulanmıştır. Bu kapsamda 27 literatür incelenerek mutlak değerlendirme parametreleri tespit edilmiştir. Bunlar topoğrafya (yükselti, eğim), toprak yapısı özellikleri (büyük toprak grupları, arazi kullanım kabiliyet sınıfları), toprak kısıtlayıcı faktörler (erozyon, tuzluluk, drenaj, taşlılık, ıslaklık, toprak derinliği), iklimsel özellikler (bakı, sıcaklık, yağış), jeomorfolojik yapı, şimdiki arazi kullanım durumudur. Araştırma alanı özelinde bu kriterlerin alt kriterleri, ölçüt ve ağırlıkları belirlenerek alan kullanım türüne göre uygunlukları değerlendirilmiştir. Uygun, uygun olmayan alanlar olarak araziler sınıflandırılmış ve derecelendirilerek “Tarım, Orman ve Çayır- Mera Peyzaj Uygunluk Haritaları" üretilmiştir. Araştırma alanın uygun alanlar toplamı (1., 2. ve 3. derece) kullanım türüne göre değerlendirildiğinde; \%46'sı tarıma uygun, \%96'sı ormana uygun, \%5'i çayır ve mera potansiyeline uygundur. Uygunluk karşılaştırması ile alanın üretim yeteneği bakımından öncelikli kullanım şekilleri belirlenmiş ve "Karma Uygunluk Haritası" oluşturularak öneriler getirilmiştir..

Anahtar sözcükler: Analitik hiyerarşi süreci; çayır-mera; coğrafi bilgi sistemi; çok kriterli karar verme süreci; ekolojik planlama; optimal uygunluk analizi; orman; tarım.

\section{ABSTRACT}

Due to the increasing population and life-needs both in the world and in Turkey, most appropriate use of natural resources should be determined. Sustainable development depends on taking the right land use decisions. Productivity of soil structure determines biomass performance of that field. This study aims to determine optimal ways of using Anamur land according to three kinds of land use: agricultural, forest, meadows-ranges. Geographic Information Systems (GIS) assisted Landscape Optimal Suitability Analysis Method (LANDEP) was used in the study. In this scope, absolute evaluation parameters were determined through the review of 27 studies from the literature. These parameters are topography (altitude, slope), soil characteristics (large soil groups, land usability groups), soil restriction factors (erosion, salinity, drainage, stoniness, wetness, soil depth), climactic features (exposure, temperature, precipitation), geomorphological structure, current land use status. Sub-criteria, standards and significance of these criteria were determined in line with the current research and their suitability were evaluated according to type of land use. Lands were classified as suitable and unsuitable lands and "Agricultural, Forest and Meadow-Range Landscape Suitability Maps" were generated through grading. When the research area was evaluated in terms of suitability $\left(1^{\text {st }}, 2^{\text {nd }}\right.$ and $3^{\text {rd }}$ grade), $46 \%$ are suitable for agriculture, $96 \%$ are suitable for forest and $5 \%$ are suitable for meadow and range. Primary land use type in terms of production capacity were determined with suitability comparison and suggestions were offered by creating "Combined Suitability Map".

Keywords: Analytical hierarchy process; meadow-range; geographic information system; multi-criteria decision-making model; ecological planning; optimal suitability analysis; forest; agriculture.

Yıldız Teknik Üniversitesi Mimarlık Fakültesi, Şehir ve Bölge Planlama Bölümü, İstanbul 


\section{Giriş}

Ülkemiz ve Dünya'da gittikçe artan nüfus ve yaşam gereksinimleri nedeniyle, doğal kaynakların sürdürülebilirliğinde en doğru ve en uygun kullanım biçimlerinin belirlenmesini zorunlu kılmaktadır. Doğal kaynakları koruyarak kullanmak, devamlılı̆ını sağlamak ekolojik planlama yaklaşımının esasıdır. Bir arazi kullanımına en uygun alanların, her toprağa en uygun arazi kullanım tipinin belirlenmesi doğal kaynakların sürdürülebilirliği için gereklidir. Bundan dolayı planlamada ekolojik bir yaklaşımla arazi potansiyellerine en uygun alanların belirlenmesi temel amaç olmalıdır. Günümüzde doğanın güvence altına alınması ve korunarak kullanılmasını amaçlayan bir planlama aracı olarak, ekolojik planlama ile ilgili yöntemler geliştirilmiştir. Ndubisi (2002)'e göre ekolojik planlama yönteminin gelişim süreci geliştirilen kişilere göre; bilinçlenme, gelişme, birleşme, kabüllenme ve çeşitlenme dönemleri olarak gruplandırılmıştir. ${ }^{1}$

Bilinçlenme Dönemi: George Catlin (1796-1872), Ralph Woldo Emerson (1803-1882), Henry D. Thoreau (18171862), Frederick L. Olmsted ve George P. Marsh (18641891).

19. yüzyılın ortalarından 20. yüzyılın başlarına kadar geçen süre içinde ekolojik planlama ile ilgili ilk temel kavramlar ortaya çıkmıştır. Olmsted, yönetim stratejileri olmadan fiziki planların tek başına sürdürülebilir olmayacağını ileri sürmüştür.

Gelişme Dönemi: Warren Manning Overlay Tekniği (1912), Patrick Geddes Bölgesel Sörvey, Geddes Metodu (1915-1929). Overlay tekniği, peyzaj mimarları ve plancılara, doğal ve kültürel faktörler arasındaki ilişkileri daha iyi yorumlamalarını sağlamış ve sentez aşamasında bu faktörleri nasıl kombine edebileceklerini göstermiştir.

Geddes modeli, sörvey çalışmaları, bölgesel peyzajın ve insanların ekonomik-kültürel aktiviteleri arasındaki ilişkilerin sistematik bir anlayışla ele alınmasına dayanmaktadır. Metodun 'insan-yapılan iş-mekan' konuları elli yıl sonra lan MacHarg tarafindan geliştirilen ekolojik planlama yönteminin de temelini oluşturmuştur.

Birleşme Dönemi: Thieneman (1926), Artur Tansley Ekosistem kavramı (1935), Carl Troll Peyzaj Ekolojisi ve Ekotop, Ekosistem Birimi kavramı (1938), Raymond Lindeman (1935-1942), Boleslaw Malisz ve Jurek Kozlowski Eşik Analiz Yöntemi (1945), Vernadsky, Benton MacKaye, Lewis Mumford Genişletilmiş Gedds Metodu, William Vogt Biyotik Denklem/Taşıma Kapasitesi kavramı, Trywhitt Genişletilmiş Overlay Tekniği (1960), MacArthur ve Wilson Biocoğrafya Adası kavramı (1967). Şehirlerde insan etkili ve doğal oluşumların nasıl birbirine geçtiğini araştırmış, bölgesel peyzaj analizi için o bölgeyi oluşturan temel faktörleri vur-

\footnotetext{
Tozar, 2006, s. 49.
}

gulayan yeni bir yaklaşım önermiştir. Bir bölgeyi oluşturan coğrafi karakter (toprak, iklim, vejetasyon, tarım), teknoloji arasındaki birbiriyle ve karşııılı etkileşimi, fiziki sınırlar olmak üzere bu üç bileşenin uyumuyla ekolojik sistemlerdeki dengenin sağlanması amaçlanmıştır.

Kabullenme Dönemi: Lewis Hopkins Metapopulasyon Teorisi, Angus Hills Fizyografik Birim Yöntemi, Biyolojik ve Fiziksel Arazi Kabiliyeti Metodu (1961), Philip Lewis Çevresel Koridorlar kavramı ve Kaynak Örneği Yöntemi, Ian McHarg Peyzaj Optimal Uygunluk Analizi- McHarg Metodu- Pennsylvania Üniversitesi Metodu (1961), Bierhals ve Ark.- Ekolojik Etkileme, Riziko Analizi Yöntemi (1974), Kapper (1974), Aulig ve Ark. (1975-1977), Gideon Golany Ekolojik Hücreleme Yöntemi (1976), Kiemstedt ve Ark., (1977), Langer ve Ark., (1977), Steinitz ve Ark. Süreçler Modeli, Lyle ve Wodtke Boston Bilgi Sistemi Yöntemi, Fabos ve Ark. Parametrik Yaklaşımlar - Metland Modeli (Metropolitan Landscape Planning Model), Steiner'ın Stratejik Uygunluk Yöntemi, Buchwald (1980). McHarg, ekolojinin peyzaj mimarisi ve bölge planlamasını yönlendirecek bir bilim olarak gelişmesi için çaba sarfetmiş, ekolojik planlama alanında önemli gelişmeler kaydetmiştir. Ekolojiyi, planlama ve tasarıma entegre eden 'Uygunluk Analizi' yöntemini geliştirmiştir. Peyzaj Optimal Uygunluk Analizi- McHarg Metodu- Pennsylvania Üniversitesi Metodu fizyografya, drenaj durumu, toprak özellikleri, doğal ve kültürel kaynakları gösteren üstüste bindirmelerle karşılaştırmalara olanak sağlayan yarı saydam overlay haritalarını kapsamaktadır.

Çeşitlilik Dönemi: Godron Forman Yöntemi, Leke-Koridor - Matriks Ekolojik Sistem Birimi, Ekotop Temelli Sınıflandırma Yöntemi (1995), Wolfgang Haber Bölgesel Doğal Birimler (RNU, Regional Naturel Unit), Wim Timmermans ve Robert Snep Habitat Ağları Tekniği (LARCH, Landscape-Ecological Analyses and Rules of Configuration of Habitat), Ruzicka ve Miklos Optimal Peyzaj Uygunluk Analizi Yöntemi (Landscape Optimal Suitability Analysis Method- LANDEP), Peyzaj Uygunluk Yaklaşımları (Landscape Suitability Approach LSA I, LSA II), Peyzaj Birimleri, Ekolojik Birimler Sınıflandırma Yöntemleri. Peyzaj Optimal Uygunluk Analizi- McHarg Metodu- Pennsylvania Üniversitesi Metodu peyzajın ekolojik yöntemler ile değerlendirilmesinde hassas fiziksel faktörleri ortaya koyar ve ekolojik problemleri araştırır. Peyzaj elemanlarının peyzaj analizi ile en uygun alan kullanım kararlarının belirlenmesini amaçlar. Arazi kullanımlarının optimizasyonu ile bir araziyi en iyi şekilde kullanmak, uygun duruma getirmek, bir araziden en iyi şekilde yararlanmak, kısıtlı koşullarda en iyileme temeline dayanmaktadır. Belirli bir amaç için bir araziye en uygun arazi kullanımları belirlemede, koşullara bağlı kısıtlardaki değişkenlerin değerini bularak en iyi değere göre en iyi kullanım kararlarını verebilmektir. 
Her kullanım türü için etken faktör, kısıtlayıcı koşulların önemini derecelendirerek ortaya koymak, o kullanım türü için önceliklerin olması esasına dayanmaktadır. Optimal Uygunluk Analizi Yöntemi ile birim alanda, değişken olarak farklı kullanımlar için koşulların ve potansiyellerin karşılaştırması yapılabilmektedir. Böylece bir arazinin her bir değişkene göre en uygun kullanım şeklini belirlemek, niteliksel ve niceliksel olarak ortaya koymak mümkündür. Bu araştırma kapsamında Anamur illçesi örneğinde tarım, orman ve çayır-mera potansiyeli bakımdan CBS destekli Optimal Uygunluk Analizi Yöntemi ile en uygun arazilerin belirlenmesi amaçlanmıştır.

\section{Araştırma Alanı Anamur İlçesi Başlıca Coğrafi Özellikleri}

İlçe $32^{\circ} 30^{1}-32^{\circ} 56^{1}$ doğu meridyenleri ile $36^{\circ} 02^{1}-36^{\circ} 31^{1}$ kuzey paralelleri arasında, 1338 km² $^{2}$ yüzölçümü ve 39359 nüfusa sahiptir. ${ }^{2}$ Topraklarının \%53'ü 1000 m üzerinde, \%35'i Türkiye'nin en geniş karstik yapısı Taşeli Platosu üzerindedir. En yüksek rakım Sarıtaş Tepesi (2339 m), en düşük kod deniz seviyesidir (Şekil 1). ${ }^{3}$

İlçe'nin kuzeyinde Göksu Nehri, güneyinde Dragon Çayı Althavzası, doğusunda Dragon Çayı, batısında Sultanderesi yeralmaktadır (Şekil 2). ${ }^{3}$

Toprak yapısı Büyük Toprak Gruplar (BTG) bakımından Kolüviyal, Alüviyal, Kırmızı Akdeniz Toprakları, Kahverengi Orman Toprakları, Kireçsiz Kahverengi Orman Toprakları ve Arazi Kullanım Kabiliyet Sınıflaması (AKKS) bakımından II., VII. ve VIII. sınıf topraklar bulunmaktadır (MÇDP, 2015).

Jeolojik yapı bakımından Kambriyen-Tersiyer aralığında çökelmiş kaya ve en yoğun (\%44) Paleozoik birimi hakimdir. Kocatepe, Yellice, Sığırcık, Çamlık ve Güvenç formasyonları zengin yeraltısuyu içermektedir. ${ }^{4}$

İlçe Merkezi'nin kıyı kesiminde "Akdeniz İklimi", plato ve dağlık alanlarda "Akdeniz Dağ Iklimi" hakimdir. Yıllık ortalama sıcaklık bakımından Thorntwaite yöntemine göre yaz mevsiminde su noksanı okyanus iklimine yakın Akdeniz İklim Tipi'dir. Atalay ve Mortan (2006)'a göre İlçe'nin \% 60'ı orman olup, "Akdeniz Fitocoğrafya Bölgesi"ndedir. 1000-1200 m yükseltilerde "Asıl Akdeniz Kuşağı Bitki Toplulukları", 1000-2200 m'ye kadar “Akdeniz Dağ Kuşağı Ormanları", Akdeniz yönelişli yamaçlarda 2000 m'den itibaren "Subalpin Ot Toplulukları" görülmektedir (Sunkar ve Uysal, 2014).

Arazi Kullanımı durumuna (AK) göre; 4521 ha Yerleşik Alan, 8514 ha Tarım Alanı, 111.4691 ha Orman Alanı, 1.899 ha Taşlık-Kayalık Alan, 459,1 ha Mera Alanı, 456,2 ha Su Yüzeyi, 9.6 ha KSS alanı bulunmaktadır. İlçe'nin \%83.8'ini ormanlar oluşturur, 5694ha Sera Alanı ile Mersin'deki tüm sera alanları içinde 1. sıradadır (MÇDP, 2015).

\footnotetext{
2 MÇDP, 2015. ${ }^{3}$ MÇŞiM ÇDP, 2016. ${ }^{4}$ Sunkar ve Uysal, 2014, s. 69-93.
}

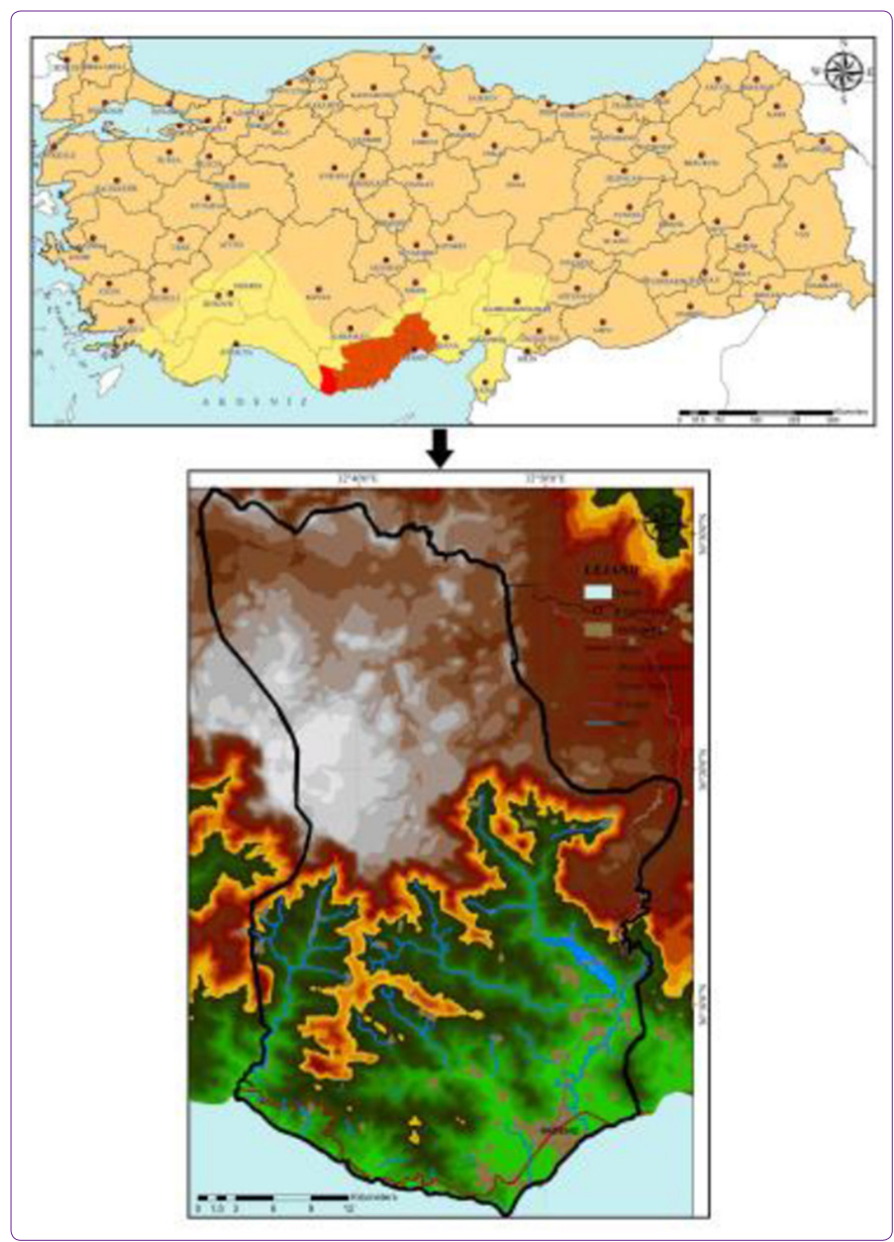

Şekil 1. Araştırma Alanı Yer Gösterim Haritası (MÇDP, 2015).

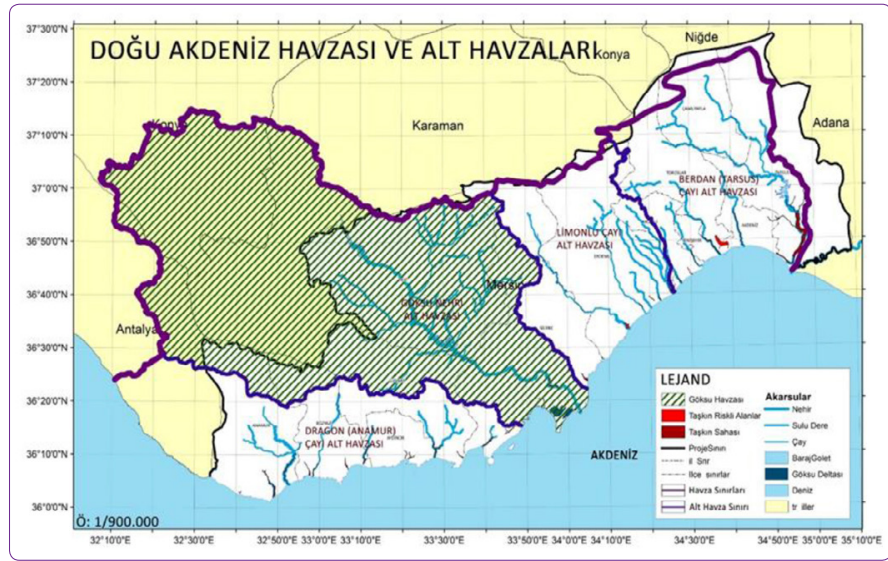

Şekil 2. Araştırma Alanı Makro Havza İlişskisi (MÇŞiM ÇDP, 2016).

\section{Anamur İlçesi Optimal Peyzaj Uygunluk Analizi Yöntemi ve Veri Seti}

Araştırma Anamur illçesi örneğinde Coğrafi Bilgi Sistemi (CBS) destekli Optimal Uygunluk Analizi Yöntemi (LANDEP) ile peyzaj potansiyellerine göre en uygun alan kullanım biçimlerinin belirlenmesi amacıyla, 2018 yılı Ocak ayında başlayan kurumsal veri toplama, alan çalışmaları ve pey- 
Tablo 1. Kaynaklara Göre Bir Arazinin Optimal Peyzaj Uygunluğunun Belirlenmesinde Değerlendirilen Kriterler ve Alt Kriterler

\begin{tabular}{|c|c|c|c|c|c|c|c|c|c|c|c|c|c|c|c|c|c|c|c|c|}
\hline \multirow[t]{2}{*}{ Kaynak } & \multicolumn{2}{|c|}{ Topoğrafik Yapı } & \multicolumn{2}{|c|}{ Toprak Yapısı } & \multicolumn{6}{|c|}{$\begin{array}{c}\text { Toprak Kısıtlayııı } \\
\text { Faktörler }\end{array}$} & \multicolumn{3}{|c|}{$\begin{array}{c}\text { Toprak } \\
\text { Özellikleri }\end{array}$} & \multirow{2}{*}{\begin{tabular}{|c|} 
Hidroloji \\
$\mathrm{H}$
\end{tabular}} & \multicolumn{3}{|c|}{ İklimsel Özellikler } & \multicolumn{2}{|c|}{ Arazi Kullanış Durumu } & \multirow{2}{*}{$\begin{array}{c}\begin{array}{c}\text { Jeoloji ve Jeomorfoloji } \\
\text { Yapı }\end{array} \\
\text { J - JM }\end{array}$} \\
\hline & YÜ & $\mathrm{E}$ & BTG & AKKS & e & $s$ & $t$ & $\mathrm{w}$ & $\mathrm{d}$ & dğ & tt & $\mathrm{td}$ & tk & & B & $S$ & Y & $U$ & ŞAK & \\
\hline $5^{5}$ & $\mathrm{x}$ & $x$ & $x$ & $\mathrm{x}$ & $\mathrm{x}$ & $\mathrm{x}$ & & & & & $\mathrm{x}$ & $\mathrm{x}$ & $\mathrm{x}$ & & & $\mathrm{x}$ & $\mathrm{x}$ & $\mathrm{x}$ & & \\
\hline 6 & $x$ & $x$ & $\mathrm{x}$ & $\mathrm{x}$ & $\mathrm{x}$ & $\mathrm{x}$ & $\mathrm{x}$ & $\mathrm{x}$ & $x$ & & & & & $\mathrm{x}$ & & & $\mathrm{x}$ & & & \\
\hline 7 & $\mathrm{x}$ & $x$ & $\mathrm{x}$ & $\mathrm{x}$ & $\mathrm{x}$ & $\mathrm{x}$ & $\mathrm{x}$ & $\mathrm{x}$ & $\mathrm{x}$ & $\mathrm{x}$ & $\mathrm{x}$ & $\mathrm{x}$ & $\mathrm{x}$ & $\mathrm{x}$ & $\mathrm{x}$ & $\mathrm{x}$ & $\mathrm{x}$ & $\mathrm{x}$ & $\mathrm{x}$ & $\mathrm{x}$ \\
\hline 8 & $\mathrm{x}$ & $\mathrm{x}$ & $x$ & $x$ & $x$ & $x$ & & & & $x$ & $x$ & & $x$ & & & & & & & \\
\hline 9 & $x$ & $x$ & & & $\mathrm{x}$ & & & & $x$ & & & $\mathrm{x}$ & & & $x$ & $\mathrm{x}$ & $x$ & $x$ & $\mathrm{x}$ & $\mathrm{x}$ \\
\hline 10 & $x$ & $x$ & & $x$ & $x$ & $x$ & $\mathrm{x}$ & $\mathrm{x}$ & $x$ & & & $x$ & & & & $x$ & $x$ & & $x$ & $x$ \\
\hline 11 & $\mathrm{x}$ & $x$ & & & & & & & & & $x$ & $\mathrm{x}$ & $x$ & & & & & & $\mathrm{x}$ & $x$ \\
\hline 12 & $\mathrm{x}$ & $x$ & & & $x$ & $x$ & $x$ & $\mathrm{x}$ & $x$ & $x$ & & $x$ & & & $\mathrm{x}$ & & & $\mathrm{x}$ & & \\
\hline 13 & $x$ & $x$ & & & $\mathrm{x}$ & $x$ & $\mathrm{x}$ & $\mathrm{x}$ & $\mathrm{x}$ & $x$ & & $x$ & & & $x$ & & & $x$ & & \\
\hline 14 & $x$ & $\mathrm{x}$ & $x$ & $x$ & $x$ & $\mathrm{x}$ & $\mathrm{x}$ & $\mathrm{x}$ & $\mathrm{x}$ & $\mathrm{x}$ & $x$ & $\mathrm{x}$ & $\mathrm{x}$ & $\mathrm{x}$ & $x$ & $\mathrm{x}$ & $\mathrm{x}$ & $\mathrm{x}$ & $\mathrm{x}$ & $x$ \\
\hline 15 & $\mathrm{x}$ & $x$ & & $\mathrm{x}$ & $\mathrm{x}$ & $\mathrm{x}$ & $\mathrm{x}$ & $\mathrm{x}$ & $\mathrm{x}$ & & & $\mathrm{x}$ & & & $\mathrm{x}$ & $\mathrm{x}$ & $\mathrm{x}$ & & $\mathrm{x}$ & \\
\hline 16 & & & $\mathrm{x}$ & $\mathrm{x}$ & & & & & $\mathrm{x}$ & & & $\mathrm{x}$ & & & & & & & $\mathrm{x}$ & $\mathrm{x}$ \\
\hline 17 & $\mathrm{x}$ & $\mathrm{x}$ & $\mathrm{x}$ & $\mathrm{x}$ & $\mathrm{x}$ & & & & & & $\mathrm{x}$ & $x$ & $x$ & & $\mathrm{x}$ & & & & & \\
\hline 18 & $\mathrm{x}$ & $\mathrm{x}$ & & $x$ & & & & & & $\mathrm{x}$ & & & & $\mathrm{x}$ & $\mathrm{x}$ & $\mathrm{x}$ & $\mathrm{x}$ & & & \\
\hline 19 & & $\mathrm{x}$ & & & - & & & & $\mathrm{x}$ & $\mathrm{x}$ & $x$ & $\mathrm{x}$ & $\mathrm{x}$ & & & & & & 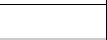 & \\
\hline 20 & $\mathrm{x}$ & $\mathrm{x}$ & & $\mathrm{x}$ & $\mathrm{x}$ & $\mathrm{x}$ & $\mathrm{x}$ & $\mathrm{x}$ & $\mathrm{x}$ & & & $x$ & $\mathrm{x}$ & $\mathrm{x}$ & $\mathrm{x}$ & $x$ & $\mathrm{x}$ & & $\mathrm{x}$ & $\mathrm{x}$ \\
\hline 21 & & $\mathrm{x}$ & & $\mathrm{x}$ & $\mathrm{x}$ & & & & & & & $\mathrm{x}$ & & $\mathrm{x}$ & & $\mathrm{x}$ & $\mathrm{x}$ & & & $\mathrm{x}$ \\
\hline 22 & $x$ & $\mathrm{x}$ & $x$ & $\mathrm{x}$ & $\mathrm{x}$ & $\mathrm{x}$ & & & & $x$ & & $\mathrm{x}$ & & & $\mathrm{x}$ & $\mathrm{x}$ & $\mathrm{x}$ & & $\mathrm{x}$ & $\mathrm{x}$ \\
\hline 23 & $\mathrm{x}$ & $\mathrm{x}$ & $\mathrm{x}$ & $\mathrm{x}$ & $\mathrm{x}$ & $\mathrm{x}$ & $\mathrm{x}$ & & 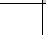 & & & $\mathrm{x}$ & & & $\mathrm{x}$ & $\mathrm{x}$ & $\mathrm{x}$ & & $\mathrm{x}$ & $\mathrm{x}$ \\
\hline 24 & & $\mathrm{x}$ & & $\mathrm{x}$ & $\mathrm{x}$ & $\mathrm{x}$ & $\mathrm{x}$ & $\mathrm{x}$ & $\mathrm{x}$ & & & $\mathrm{x}$ & & & & & & & $\mathrm{x}$ & \\
\hline 25 & $\mathrm{x}$ & $\mathrm{x}$ & $\mathrm{x}$ & $\mathrm{x}$ & $\mathrm{x}$ & $\mathrm{x}$ & $\mathrm{x}$ & $\mathrm{x}$ & $\mathrm{x}$ & $x$ & $x$ & $\mathrm{x}$ & $x$ & $\mathrm{x}$ & $x$ & $x$ & $x$ & $\mathrm{x}$ & $\mathrm{x}$ & $\mathrm{x}$ \\
\hline 26 & & $x$ & $\mathrm{x}$ & & $\mathrm{x}$ & & & & & & & $\mathrm{x}$ & & & & & & & $\mathrm{x}$ & \\
\hline 27 & $\mathrm{x}$ & $x$ & $\mathrm{x}$ & $x$ & $x$ & $\mathrm{x}$ & $\mathrm{x}$ & $\mathrm{x}$ & $\mathrm{x}$ & $\mathrm{x}$ & $x$ & $\mathrm{x}$ & $\mathrm{x}$ & $\mathrm{x}$ & $\mathrm{x}$ & $\mathrm{x}$ & $\mathrm{x}$ & $\mathrm{x}$ & $\mathrm{x}$ & $\mathrm{x}$ \\
\hline
\end{tabular}

(YÜ) Yükselti, (E) Eğim, (BTG) Büyük Toprak Grupları, (AKKS) Arazi Kullanım Kabiliyet Sınıflaması,Toprak Kısıtlayıcı-Tahtid Faktörleri (e) Erozyon, (s) Tuzluluk, (t) Taşılıı, (w) Islaklık, (d) Drenaj, (dğ) Diğer toprak özellikleri,Toprak Özellikleri (tt) Toprak Tekstürü, (td) Toprak Derinliği, (tk) Toprak Kıvamı, Organik Madde içeriği, (H) Hidroloji ve Litolojik Yapı, Taban Suyu, Yeraltısuyu, Taşkın Durumu, İklimsel Özellikler (B) Bakı, (S) Sıcaklık, (Y) Yağış, Arazi Kullanış (U) Ulaşım, Yola Yakınlık, Erişim, (ŞAK) Şimdiki Arazi Kullanımı, Güncel Arazi Kullanış, Corine Arazi Örtüsü, (J) Jeoloji ve Jeomorfolojik Yapı, Jeolojik Formasyonlar, Vadi, Vadi Tabanı, Taban Arazisi, Ova, Seki, Yamaç, Alçak Plato, Yüksek Plato, Dağlık Alan.

zaj analizlerini içermektedir. Bu kapsamda öncelikle ilgili literatür ve araştirmaların kavram, analiz, yöntem ve değerlendirmeleri üzerinde yoğunlaşılarak irdelemeler yapılmıştır. Bir arazi için en uygun arazi kullanım tipinin belirlenmesinde ortak yaklaşım "Optimal Uygunluk Analizi" farklı kriterlere göre rölatif nitel ve nicel ağıllıklar atama, puanlama ve sıralamada kolaylık sağlayan bir yöntem olarak kullanılmaktır. Bu araştırmalarda bir arazinin potansiyeline bağlı olarak kullanılan veri seti, kriter ve alt kriterlere göre parametre ağırlı̆̆ı ve kullanım türüne bağlı değişen ölçütleri bir tabloda toplanarak, karşılaştırmalarla saptamalar yapılmıştr (Tablo 1). Çeşitli coğrafya ve uzmanlıklara göre toplam 27 literatür ve araştırma değerlendirilmiş, araştırma alanı özelinde 11 ana kriter, 70 alt kriter ele alınmış ve ağılıkları belirlenmiştir (Tablo 2).

Günümüze kadar arazi kullanımların belirlenmesine yönelik pek çok araştırma yapılmıştır. Bu araştırma kapsamında "Ekolojik Yaklaşım" temelli yaklaşık 50 araştırma incelenmiş olmakla birlikte ancak 27 literatüre yer verilebilmiştir.

\footnotetext{
Wang, 1994, s.265, 6. Kalogirou, 2002, s.89, 7. Atabay, vd. 2005 a, b, c, d, e, 8. Perveen, vd. 2007, 9. Zengin vd. 2008, s.43, 10. Katen, 2008, 11. Bandyopadhyay, vd. 2009, s.875, 12. Cengiz, vd. 2009, 13. Akbulak, 2010, s.557, 14. Ayaşlıgil, 2011, s.55, 15. Demir, vd. 2011, s.77, 16. Mansuroğlu, vd. 2012 s.255, 17. Akıncı, vd. 2012, s.10, 18. Feizizadeh, vd,.2012, 19. Dengiz, vd. 2013, s.101, 20.Yeşil, vd. 2013, s.63, 21.Çelikyay, vd. 2015, s.76, 22. Çağlayan ,vd. 2016, s.83, 23. Esen, 2016, s.176, 24. Alkan, vd, 2016, 25. Ayaşlıgil, 2017, s. 514, 26. Saykılı, vd. 2017, s.126, 27. Erbesler Ayaşlıgil, 2019, s.173.
}

Arazi kullanım biçimi bakımından tarım, orman ve çayır mera uygunlukları kapsamında yapılan araştırmalara öncelik verilmiştir.

Seçilen bu literatürlerle kriterler ve alt kriterler bakımından karşılaştırma yapmak, araştırma konularına göre ortak kriter kabüllerinin ortaya konması, mutlak değerlendirme parametrelerinin öne çıkarılması amaçlanmıştır.

$\mathrm{Bu}$ araştırmaların veri setinde parametrelerin seçilmesinde uzmanlıklara göre hassasiyetlerin ve öncelikli ölçme kriterlerin vurgulanması amaçlanmıştır.

Coğrafi Bilgi Sistemi (CBS) destekli Analitik Hiyerarşik Süreç (AHS), Optimal Uygunluk Analizi (LANDEP) ortak yöntem kullanımıdır.

Veri seti oluşturma aşamasında öncelikle ArcGIS 9.3.1 yazılımı ile 1/ 50000 ölçekli Sayısal Yükseklik Modeli (SYM) oluşturulmuştur. 11 ana, 70 alt kritere ait ham veri seti oluşturularak "Yükselti Analizi, Bakı Analizi, Eğim Analizi, Şimdiki Arazi Kullanımı Analizi, Arazi Kullanım Kabiliyet Sınıf Analizi, Büyük Toprak Grupları Analizi, Jeomorfolojik Yapı Analizi, Sıcaklık ve Yağış Analizi” yapıımıştor (Tablo 1).

Ekolojik Hücreleme Yöntemi'ne göre (Golany Model) 100×100 m. grid sistemde karelere bölünerek, ESRI GRID formatına dönüştürülerek ekolojik eşit hücreler oluşturulmuştur. 
Tablo 2. Tarım, Orman ve Çayır-Meraya Uygunluk Analizi Kriterleri ve Ağırlıkları

Uygunluk Analizi Ana Kriterleri ve Alt Kriterleri

Kriter Ağırlıkları (\%)

Eğim Durumu- Eğim Yüzdesi (E)

16

Arazi Kullanım Kabiliyeti Sınıflaması (AKKS)

Büyük Toprak Grupları (BTG)

Şimdiki-Güncel -Aktüel Arazi Kullanımı (ŞAK)

16

Yükselti Durumu -Yükselti Aralıkları (YÜ)

Toprak Kısıtlayıcı -Tahtid Faktörleri: Erozyon (e), Tuzluluk (s), Taşılık (t), Islaklık (w), Drenaj (d)

Diğer Toprak Özellikleri (dğ), Toprak Tekstürü (tt), Toprak Kıvamı (tk)

7 Toprak Derinliği (td)

5

Jeolojik ve Jeomorfolojik Yapı (JM)

Bakı -Yöneliş-Güneşlenme Durumu (B)

Sıcaklık Değerleri, Yıllık Ortalama Sıcaklık (S)

Yağış Değerleri, Yıllık Ortalama Yağış (YĞ)

Kaynak: Tablo 1'e göre geliştirilmiş Anamur ilçesi araştırma alanı özeline uyarlanmıştır.

Ağırlıklı Toplam Analizi'ne göre (Weighted Sum Analysis) araştırma alanı arazilerinin tarım, oman ve çayır mera potansiyeli uygunlukları 1., 2., 3. derece uygun, uygun değil olmak üzere derecelendirilerek, değerlendirmeye hazır katmanlar haline getirilmiştir.

Çakıştırma-Bindirme Analizi'ne göre (Overlay Analysis) bu üç optimal uygunluk analizi haritaları her bir kullanım türü için CORINE arazi örtüsü veri ve güncel arazi kullanım durumu haritası ile çakıştırılarak en uygun alanlar seçilmiştir. Her bir kullanım türü için Optimal Uygunluk Haritaları ile önceliklere göre tercihlemelerle karma uygunluklar belirlenmiş, Karma Uygunluk Haritası oluşturulmuştur (Şekil 3, Tablo 3).

\section{Bulgular}

Bu araştırmanın en önemli bulgularından biri arazi uygunluklarının belirlenmesi amacıyla yapılan 27 farklı araştırma, literatür ve çeşitli uzman görüşlerine göre veri setinin bir tabloda toplanarak irdelenmesidir. Buna göre bir arazinin potansiyel alan kullanımlarının belirlenmesinde kullanılabilecek kriter, alt kriter ve ağırlıklar uzmanlıklara göre değişmekle birlikte ortak kabüllerin olmasıdır. Belirli kriterlerin mutlak ve ağırlıklı, olmazsa olmaz parametre olarak öncelikle ele alınarak kullanıldığı, vazgeçilmez ölçüt olduğu saptanmışttr.

Optimal Uygunluk Analizi Yöntemi uygulamalarında "Arazi Kullanım Kabiliyeti Sınıflaması, Büyük Toprak Grupları, Eğim Durumu, Güncel Arazi Kullanım Durumu, Yükselti Aralıkları, Toprak Derinliği, Toprak Kısıtlayıcı Faktörler, Jeomorfolojik Konum, Bakı -Yöneliş, Sıcaklık, Yağış" başlıca bu 11 kriterin baskın-dominant ölçüt olarak ele alındığı belirlenmiştir. Bu ana kriterlerden ise "Arazi Kullanım Kabiliyeti Sınıflaması, Büyük Toprak Grupları, Eğim Durumu" parametresi en yüksek ağırlıktadır.

Arazi kullanım biçimine göre elverişlilikler en uygun alanlar 1 . derece, 2 . derece, 3 . derece ve uygun olmayan alanlar olmak üzere derecelendirilmekte, Güncel Arazi Kullanım Durumu ile karşılaştırmalarla değerlendirilerek "Optimal Uygunluk Analizi Haritası" oluşturulmaktadır. Her uygunluğu araştrılan arazi kullanım biçimi için önceliklerine göre tercihlemelerle "Karma Uygunluk Haritası" elde edilmektedir.

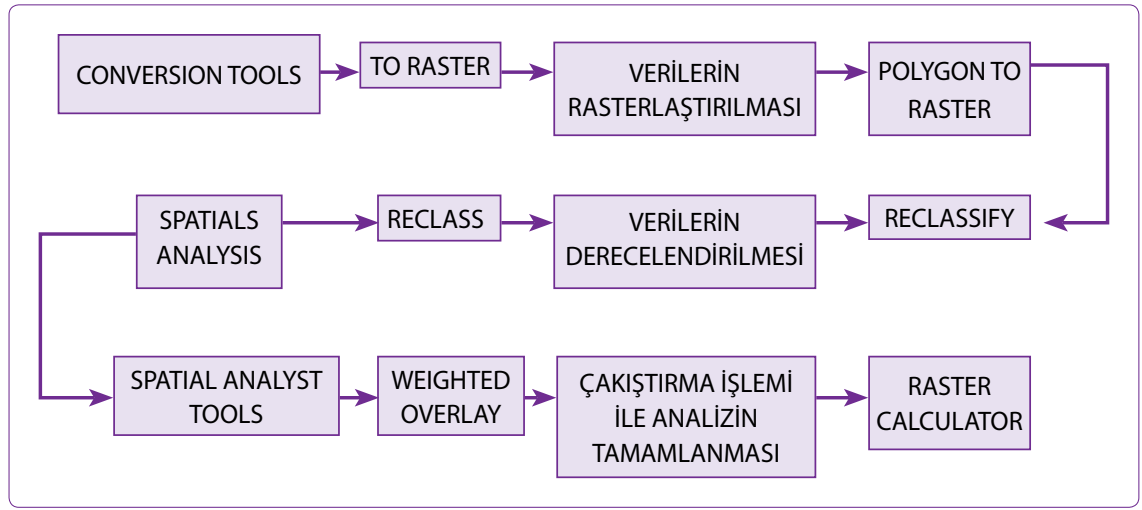

Şekil 3. Optimal Peyzaj Uygunluk Analizi Süreç Şeması. 
Tablo 3. Araştırma Alanı Tarım, Orman, Çayır-Mera Potansiyeli Bakımından Uygunluk Analizi Değerlendirme Kriterleri, Alt Kriterleri, Kriter Ağırlıkları, Ölçütleri

\begin{tabular}{|c|c|c|c|c|c|c|c|c|}
\hline \multirow{2}{*}{ KRITTERLER } & \multirow{2}{*}{\multicolumn{2}{|c|}{ ALT KRITERLER }} & \multicolumn{6}{|c|}{ POTANSİYELLERE GÖRE ÖLÇÜTLER VE AĞIRLIKLARI } \\
\hline & & & $\begin{array}{l}\text { Kriter } \\
\text { Ağırlığı }\end{array}$ & $\begin{array}{l}\text { TARIM } \\
\text { POTANSIYEL } \\
\text { İ } \\
\text { ÖLÇÜTÜ } \\
\end{array}$ & $\begin{array}{l}\text { Kriter } \\
\text { Ağırlığ1 }\end{array}$ & $\begin{array}{l}\text { ORMAN } \\
\text { POTANSIYYELI } \\
\text { ÖLÇÜTÜ }\end{array}$ & $\begin{array}{l}\text { Kriter } \\
\text { Ağırlığı }\end{array}$ & $\begin{array}{l}\text { ÇAYIR } \\
\text { MERA } \\
\text { ÖLÇÜTÜ }\end{array}$ \\
\hline \multirow{11}{*}{$\begin{array}{l}\text { ŞìDİKİ } \\
\text { GÜNCEL- } \\
\text { AKTÜEL } \\
\text { ARAZİ } \\
\text { KULLANIMI } \\
\text { (ŞAK) }\end{array}$} & \multicolumn{2}{|c|}{ Kuru ve Sulu Tarım Alanı } & \multirow[b]{2}{*}{3} & \multirow[t]{11}{*}{ 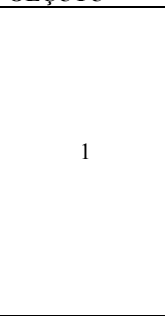 } & 1 & \multirow{11}{*}{1} & & \\
\hline & Bağ ve & ahçelik Alanı & & & 1 & & 1 & \\
\hline & Düşük & oğun Bitki Alanı & 2 & & 3 & & & \\
\hline & Çayır & Mera Alanı & 1 & & 2 & & 3 & \\
\hline & Ağaçlı & Funda, Çalılık, Makilik & & & 3 & & 2 & \\
\hline & Orman & lanı & & & 3 & & 0 & 1 \\
\hline & Tuzcul & itki Alanı, Kumul & & & & & 0 & \\
\hline & Batakl & Islak Alan & & & 1 & & 1 & \\
\hline & Çıplak & ayalık, Molozlar & 0 & & & & 2 & \\
\hline & Yerleş & Alanı & & & & & & \\
\hline & Su Yü & yleri & & & 0 & & 0 & \\
\hline & Vadi T & anı, Taban Arazisi & & & & & 3 & \\
\hline JEOMORFOLOJI & Seki, Y & maç & 3 & & 1 & & 3 & \\
\hline (JM) & Ova A & & & 1 & & 1 & 1 & 1 \\
\hline & Alçak & & 2 & & & & 2 & \\
\hline & Yükse & lato & 1 & & 2 & & 3 & \\
\hline & Dağlık & & 1 & & & & 2 & \\
\hline & Alüvy & Topraklar & 3 & & 1 & & 1 & \\
\hline & Kollov & al Topraklar & 2 & & 1 & & 1 & \\
\hline & Regos & Topraklar & 1 & & 1 & & 2 & \\
\hline BÜYÜK & Kahve & gi Orman Toprakları & & 3 & & 3 & 1 & 3 \\
\hline $\begin{array}{l}\text { TOPRAK } \\
\text { GRUPLARI }\end{array}$ & $\begin{array}{l}\text { Kirm12 } \\
\text { Topral }\end{array}$ & $\begin{array}{l}\text { Kahverengi Akdeniz } \\
\text { r1 }\end{array}$ & 3 & & 3 & & 2 & \\
\hline (BTG) & $\begin{array}{l}\text { Kireçs } \\
\text { Topral }\end{array}$ & $\begin{array}{l}\text { Kahverengi Orman } \\
\text { r1 }\end{array}$ & 1 & & & & 3 & \\
\hline & Kirmı & Akdeniz Toprakları & & & 1 & & 1 & \\
\hline & Rendiz & Topraklar & 0 & & 3 & & 3 & \\
\hline & I. sinif & KKS & 3 & & & & & \\
\hline ARAZI & II. $\sin 1$ & KKS & 2 & & 0 & & 0 & \\
\hline KULLANIM & III. $\sin$ & AKKS & 1 & & & & & \\
\hline KAABİLIYET & IV. $\sin$ & AKKS & 1 & 3 & 1 & 3 & 3 & 3 \\
\hline SINIFLAMASI & V. $\sin 1$ & KKS & & & 1 & & 3 & \\
\hline & VI. sin & AKKS & & & 2 & & 2 & \\
\hline & VII. S1 & AKKS & 0 & & 3 & & 1 & \\
\hline & VIII. s & f AKKS & & & 0 & & 0 & \\
\hline & & Hiç Yok veya Çok Az & 1 & & 1 & & 1 & \\
\hline & Erozy & Orta & -1 & & 0 & & 1 & \\
\hline & on (e) & Șiddetlí, Çok Şiddetli & -2 & & -1 & & -1 & \\
\hline TOPRAK & & Hafif Tuzlu-Alkali & 1 & & 1 & & & \\
\hline KISITLAYICI & Tuzlu & Tuzlu-Alkali & -1 & 1 & -1 & 1 & 1 & 1 \\
\hline (TAHTİD) & luk & Tuzlu & -2 & & -2 & & & \\
\hline FAKTÖRLER & (s) & Alkali & -1 & & 0 & & 0 & \\
\hline & Taşlı & & -1 & & 1 & & 1 & \\
\hline & Islakl1 & w) & 0 & & 0 & & 0 & \\
\hline & Topral & 1sitlayıcı engeli yok & 2 & & 2 & & 2 & \\
\hline & Derin & prak $(110 \mathrm{~cm}<)$ & 3 & & 3 & & 3 & \\
\hline TOPRAK & Orta D & in Toprak $(109-75 \mathrm{~cm})$ & 2 & & 2 & & 2 & 1 \\
\hline DERİNLİĞİ & $\mathrm{S} 1 \breve{g} \mathrm{To}$ & ak $(74-20 \mathrm{~cm})$ & 1 & 1 & 1 & 1 & 1 & \\
\hline (TD) & Çok S & Toprak $(20-0 \mathrm{~cm})$ & 0 & & 0 & & 1 & \\
\hline & $0-400$ & & & & 0 & & & \\
\hline & $400-8$ & & 3 & & & & 2 & \\
\hline YÜKSELTİ & $800-1$ & & & & 2 & & & \\
\hline ARALIKLARI & $1500-2$ & $0 \mathrm{~m}$ & 2 & 2 & 3 & 2 & & 2 \\
\hline & $2000-$ & $00 \mathrm{~m}$ & & & & & 3 & \\
\hline & $2400-3$ & $0 \mathrm{~m}$ & 0 & & 0 & & & \\
\hline & $3200 \mathrm{n}$ & & & & & & 1 & \\
\hline & $\% 0-1$ & & 3 & & 1 & & 3 & \\
\hline EĞİM YÜZDESİ & $\% 12-$ & & 2 & 3 & 1 & 3 & 2 & 3 \\
\hline & $\% 20-3$ & & 1 & & 2 & & 1 & \\
\hline & $\% 30$ & & 0 & & 3 & & 1 & \\
\hline BAKI *YÖNELIŞ & Düz & $x_{0}$ & 3 & & 2 & & 3 & \\
\hline DURUMU & Güney & üneydoğu, Güneybatı, Batı & 2 & & 3 & & 3 & \\
\hline (B) & Kuzey & uzeydoğu, Kuzeybatı & 1 & 1 & 2 & 1 & 2 & 1 \\
\hline & Doğu & & 3 & & 3 & & 3 & \\
\hline YILLIK & $15-20^{\circ}$ & & 3 & & 1 & & 1 & \\
\hline ORTALAMA & $15-10^{\circ}$ & & 2 & 3 & 2 & 3 & 2 & 3 \\
\hline SICAKLIK (S) & $10-5^{\circ} \mathrm{C}$ & & 1 & & 3 & & 3 & \\
\hline & $1500-$ & $50 \mathrm{~mm}$ & & & 1 & & 1 & \\
\hline YILLIK & $1250-$ & $0 \mathrm{~mm}$ & 0 & 3 & 2 & 3 & 2 & 3 \\
\hline ORTALAMA & $1000-$ & $0 \mathrm{~mm}$ & & & 3 & & 3 & \\
\hline YAĞISS (YĞ) & $921-10$ & $\mathrm{~mm}$ & 3 & & 0 & & 0 & \\
\hline & $0-921$ & & & & & & & \\
\hline
\end{tabular}

Kaynak: Tablo 1'e göre geliştirilmiş ve araştırma alanı özeline uyarlanmıştır. 
Arazi kullanımına kararlarında etken faktörler alanının özelliklere göre değişmektedir. Araştırmada örnek alan özelinde bu 11 ana kriter ve 70 alt kriter saptanmıştır (Tablo 3).

Tarıma uygunluğun belirlenmesinde Arazi Kabiliyet Sınıflaması (I. sınıf olmadığı için II. sınıf ), Büyük Toprak Grupları (Alüvyal, Kırmızı Akdeniz Toprakları), Eğim \%0-12 (Düz alanlar), Güncel Arazi Kullanımı (Kuru ve sulu tarım alanları, Bağ ve bahçelik, Sera alanı, Örtüaltı yetiştiricilik alanı, Açık tarım toprağı alanı), Yükselti (0-1500 m), Jeomorfolojik Yapı (Vadi tabanı, taban arazisi, seki, yamaç, ova alanı), Toprak Derinliği (Derin topraklar $110 \mathrm{~cm}$ 'den büyük), Yöneliş- Bakı (Güneşli bakılar), Yıllık Ortalama Sıcaklık $\left(15-20^{\circ} \mathrm{C}\right)$, Yıllık Ortalama Yağış (0-921 mm) en yüksek ağırlıklı kriterlerdir.

Ormana uygunluğun belirlenmesinde Arazi Kabiliyet Sınıflaması (VII. sınıf AKKS), Büyük Toprak Grupları (Kahverengi Orman Toprakları, Kırmızı Kahverengi Akdeniz Toprakları, Kireçsiz Kahverengi Orman Toprakları, Rendiza Toprakları), Eğim Durumu \%30'den büyük (Eğimli alanlar), Güncel Arazi Kullanımı (Ağaçlık, Fundalık, Çalıık, Makilik, Orman, Düşük yoğunluklu bitki alanı), Yükselti (1500-2000 $\mathrm{m})$, Jeomorfolojik Yapı (Alçak plato), Toprak Derinliği (Derin topraklar 110 cm'den büyük), Yöneliş-Bakı (Güneşli bakı- lar), Yıllık Ortalama Sıcaklık (10-5ㄷ), Yıllık Ortalama Yağış (1000-1250 mm) en yüksek ağırlıklı kriterlerdir.

Çayır-meraya uygunluğun belirlenmesinde Arazi Kabiliyet Sınıflaması (IV. ve V. sınıf AKKS), Büyük Toprak Grupları Kireçsiz Kahverengi Orman Toprakları, Rendiza Topraklar), Eğim Durumu \%0-12 (Düz alanlar), Güncel Arazi Kullanım Durumu (Çayır-Mera alanları), Yükselti (1500-3200 m yükselti aralı̆ıı), Jeomorfolojik Yapı (Vadi tabanı, taban arazisi, seki, yamaç, dağlık alan), Toprak Derinliği (Derin topraklar $110 \mathrm{~cm}$ 'den büyük), Yöneliş-Bakı (Güneşli bakılar), Yıllık Ortalama Sıcaklık $\left(10-5^{\circ} \mathrm{C}\right)$, Yıllık Ortalama Yağış (1000-1250 $\mathrm{mm}$ ) en yüksek ağırlıklı kriterlerdir. Yükselti analizine göre araştırma alanının \%24.8'i 1-500 m, \%22.5'i 500-1000 m $\% 12.2$ 'si $1000-1500 \mathrm{~m} \% 31.7$ 'si $1500-2000 \mathrm{~m}$ ve $\% 8.8^{\prime} \mathrm{i}$ 2000 m üzerindedir (Şekil 4a).

Bakı analizine göre alanın \%14'ü Kuzey, \%13.4'ü Kuzeydoğu, \%13.5'i Doğu, \%0.2'si Güneydoğu, \%23'ü Güney, \%17.3'ü Güneybat, \%10'u Bat, \%8.6'sı Kuzeybat yöneliştedir. Alanın \%77'si \%0-20 eğim ve \%64'ü güneşli bakıdadır (Şekil 4b).

Eğim analizine göre araştırma alanın \%37'si \%0-5, \%7'si \%5-10, \%6'sı \%10-15, \%27'si \%15-20, \%4'ü \%20-25, \%3'i 25-30, \%6'sı \%30-35, \%10'u \%35 ve üzeri eğim aralığında-

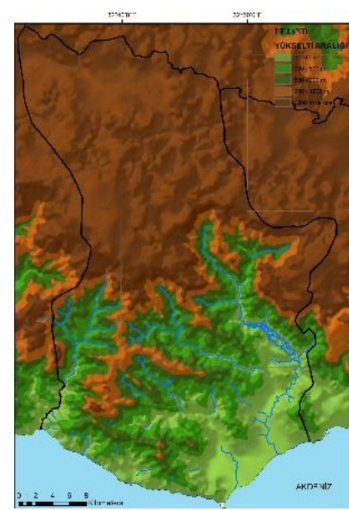

(a)

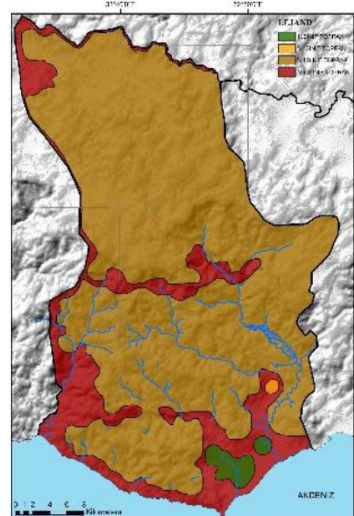

(e)

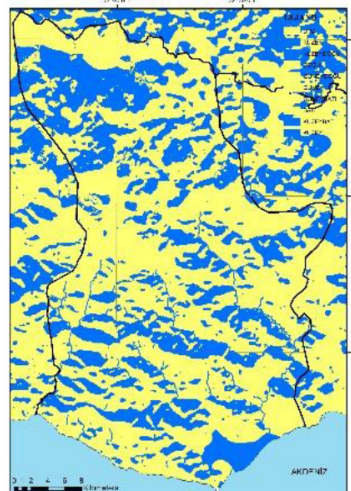

(b)

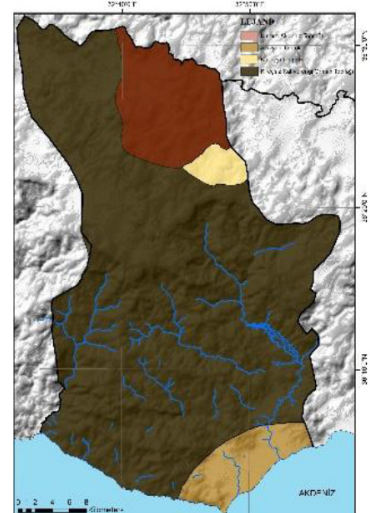

(f)

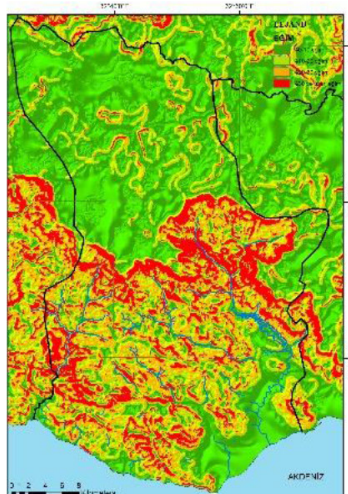

(c)

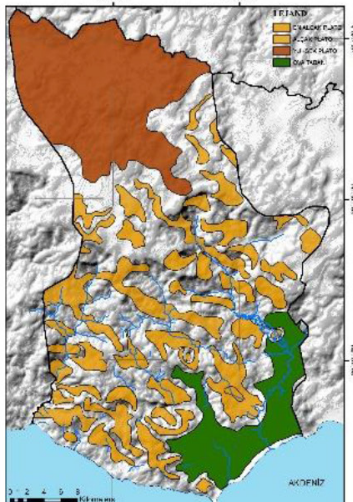

(g)

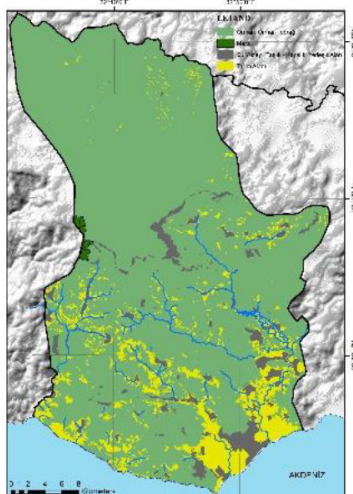

(d)

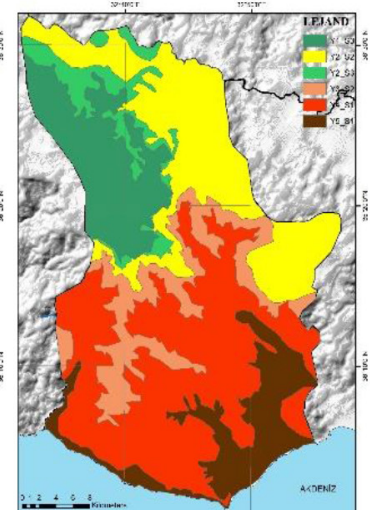

(h)

Şekil 4. Optimal Peyzaj Uygunluk Analizi'nde Kullanılan Veri Seti. (a) Yükselti Analizi, (b) Bakı Analizi, (c) Eğim Analizi, (d) Şimdiki Arazi Kullanımı Analizi, (e) Arazi Kullanım Kabiliyet Sınıfı Analizi, (f) Büyük Toprak Grupları Analizi, (g) Jeomorfolojik YapıAnalizi, (h) Sıcaklık ve Yağış Analizi. 
Tablo 4. Arazi Kullanım Türüne Uygunluk Durumunun Alansal ve Oransal Dağılımı

\begin{tabular}{|c|c|c|c|c|c|c|}
\hline \multirow{3}{*}{$\begin{array}{l}\text { Arazi Kullanım Biçimine Göre } \\
\text { Alan Uygunluk Durumu }\end{array}$} & \multicolumn{6}{|c|}{ Arazi kullanım biçimi } \\
\hline & \multicolumn{2}{|c|}{ Tarım Alanı } & \multicolumn{2}{|c|}{ Orman Alanı } & \multicolumn{2}{|c|}{ Çayır ve Mera Alanı } \\
\hline & ha & $\%$ & ha & $\%$ & ha & $\%$ \\
\hline 1. derece uygun alan & 1338 & 1 & 2676 & 1 & 3014 & 0.03 \\
\hline 2. derece uygun alan & 8028 & 6 & 68238 & 52 & 69590 & 55 \\
\hline 3. derece uygun alan & 52182 & 39 & 57534 & 43 & 54830 & 44 \\
\hline Uygun olmayan alan & 72252 & 54 & 5352 & 4 & 6366 & 0.97 \\
\hline Toplam & 133800 & 100 & 133800 & 100 & 133800 & 100 \\
\hline
\end{tabular}

dır. İlçe yerleşimi \%50’si düz, düze yakın arazi \%0-15 eğimdedir (Şekil 4c).

Güncel arazi kullanım analizine göre Kuru Tarım ve Sulu Tarım Alanı \%10.72, Çayır ve Mera Alanı \%0.64, Ağaçlık, Funda, Çalııı, Makilik ve Orman Alanı \%85.50, Çıplak Kayalık, Molozlar, Yerleşim \%4.85, Su Yüzeyleri, Kıyısal Alan \%0.07 oranındadır. Merkez İlçe'nin \%72'sini Ova Tabanı, $\% 28$ 'ini Plaj ve Bataklık Alandadır (Şekil 4d).

Arazi kullanım kabiliyetine göre alanın \%80'i (107.843 ha) VII. sınıf, \% 17.5'i (23.330 ha) VIII. sınıf, \%2'si (2.119 ha) II. sınıf, 0.1'i (210 ha) VI. sınıf arazidir (Şekil 4e).

Büyük toprak grupları analizine göre alanın $\% 81^{\prime} i$ (108.386 ha) Kireçsiz Kahverengi Toprak, \%11'i (14.754 ha) Kırmızı Akdeniz Toprağı, \%6'sı (7.900 ha) Alüvyal Toprak, \%2'si (2.458 ha) Kolüvyal Topraklar, \%0.002'si (4 ha) çıplak kayalıktır (Şekil 4f).
Jeomorfolojik yapı analizine göre araştırma alanın, \%70'i ova alanı ve tabanı, \%30'u alçak plato, yüksek plato, dağlık alandan oluşmaktadır (Şekil 4g).

iklim durumu yıllık ortalama sıcaklık ve yağış analizine göre bölgelemede alanın \%11.5'i Y5-S1 (Y5:0-921.6 mm., $\mathrm{S} 1: 15-20^{\circ} \mathrm{C}$ ), \%34.5'i Y4-S1 (Y4:921.6-1000 mm., S1:15$\left.20^{\circ} \mathrm{C}\right)$, \%11.5'i Y3-S2 (Y3:1000-1250 mm., S2:10-15 $\left.{ }^{\circ} \mathrm{C}\right)$, $\% 22.9^{\prime}$ u Y2-S2 (Y2:1250-1500 mm., S2:10-15 ${ }^{\circ} \mathrm{C}$ ), \%5.9'u Y2-S3 (Y2:1250-1500 mm., S3:5-10 $\mathrm{C}$ ), \%13.7'si Y1-S3 (Y1:1500-1750 mm., S3:5-10 C) kapsamaktadır (Şekil 4h).

Optimal Uygunluk Analizlerine göre Anamur İlçe'nin tarım, orman ve çayır-mera arazi kullanım türlerine uygun arazilerin büyüklükleri ve oransal dağılımı belirlenmiştir (Tablo 4, Şekil 5a-c). Tarıma 1., 2., ve 3. derece uygun araziler toplamı 61548 ha ve \%46 oranında, tarıma uygun olmayan araziler 72252 ha ve \%54 oranındadır (Tablo 4, Şekil 5a). Ormana 1., 2., ve 3. derece uygun araziler toplamı

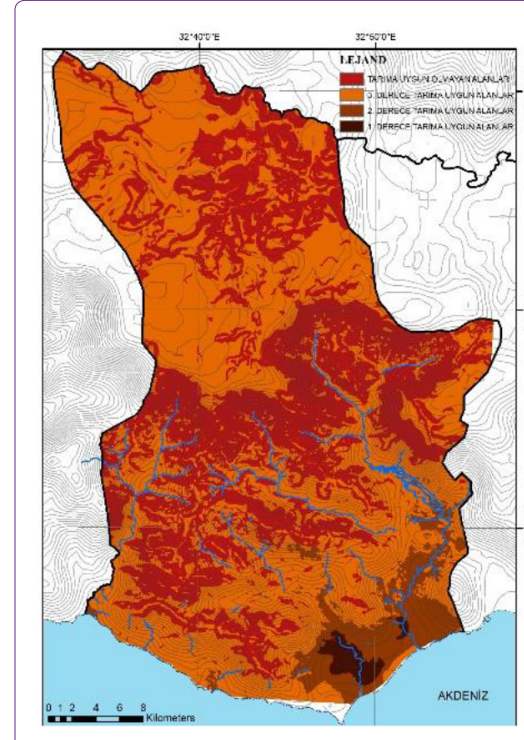

(a)

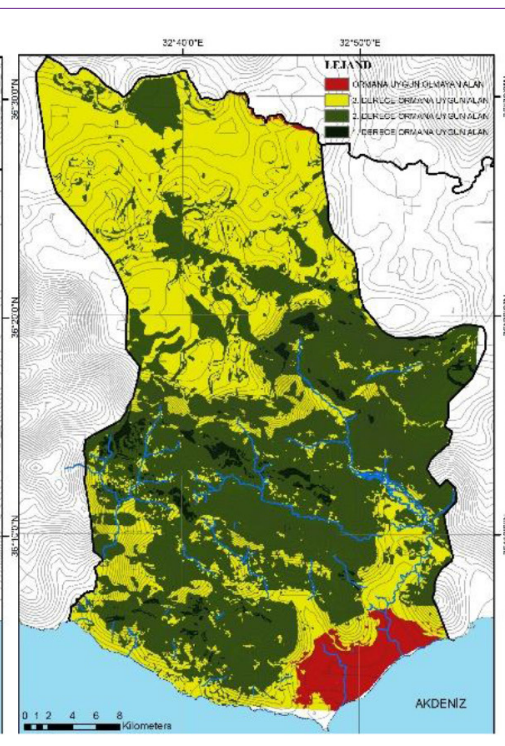

(b)

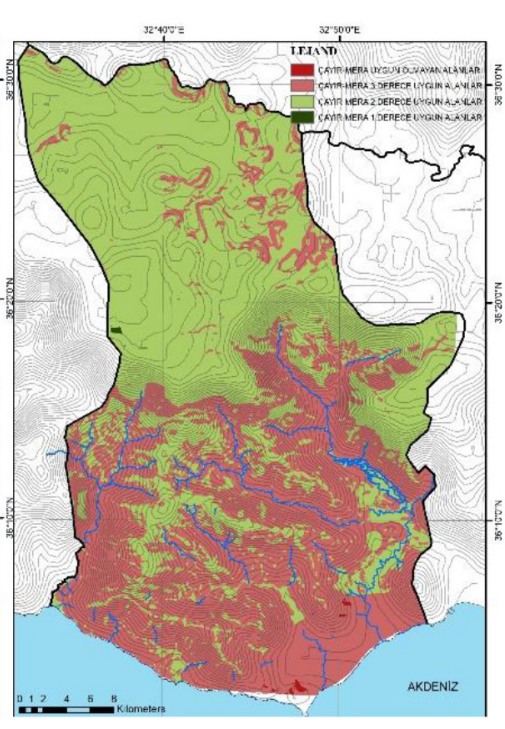

(c)

Şekil 5. Optimal Uygunluk Analiz Haritaları. (a) Tarıma Uygunluk Analizi Haritası, (b) Orman Uygunluk Analizi Haritası, (c) Çayır-Meraya Uygunluk Analizi Haritası. 


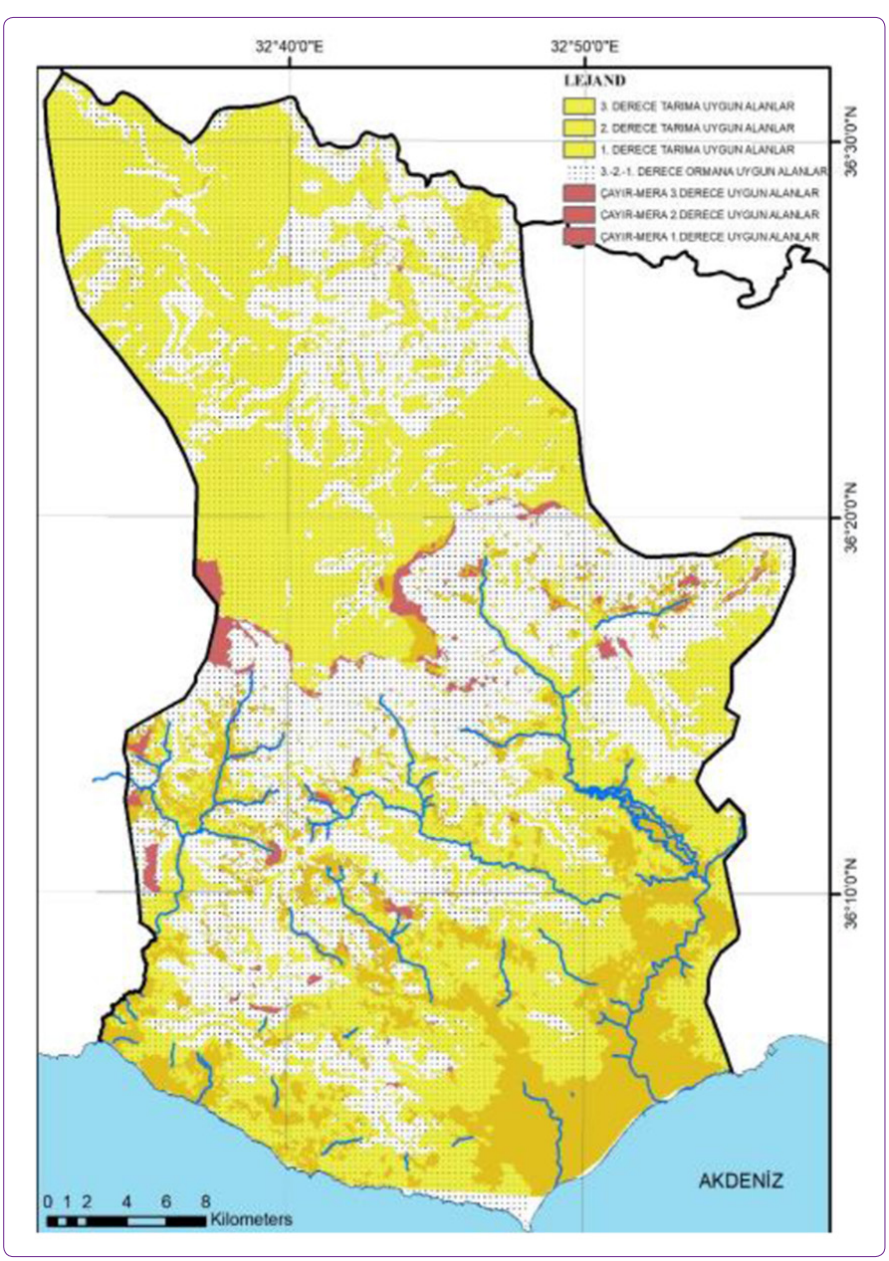

Şekil 6. Araştırma Alanı Anamur İlçesi Karma Uygunluk Haritası.

128448 ha ve $\% 96$ oranında, ormana uygun olmayan araziler 5352 ha ve $\mathrm{p} \% 4$ oranındadır (Tablo 4, Şekil 5b). Çayırmeraya 1., 2., ve 3. derece uygun araziler toplamı 127434 ha ve \%95 oranında, çayır-meraya uygun olmayan araziler 6366 ha ve \%5 oranındadır (Tablo 4, Şekil 5c).

ilç̧e genelinde II. sınıf arazi kabiliyetinde topraklar tarım için en elverişli alanlar olup ilçe topraklarının \%2'sini oluşmaktadır. Güncel arazi kullanımı ile karşılaştırıldığında bunun \%1'i yerleşim ile diğer \%1'i yine Merkez illçe'de örtü alt yetiştiriciliği ve sera alanları ile kaplandığı saptanmıştır (Şekil 6).

Anamur Ovası, Büyükova (Tarımsal Sit Alanı) brüt 3775 ha. alanın \%13.74'ü (518,14 ha) yerleşim alanı, \%7.48'i (282,637 ha) Taşkın Alanı, \%2.05'i (77,605 ha) Sit Alanıdır. ilç̧enin \%2.83'ü yerleşmenin \%11.6'sı Büyükova sınırları içindedir. İlçenin \%18.79'u (25035,26 ha), yerleşim alalının $\% 12.91$ 'i $(575,47$ ha) alan Havza Koruma alanı içindedir. IIIçenin \%90.42'si (120471,465 ha) Havza Koruma ve Orman Koruma Alanı olup geriye kalan \%3.34'ü (4456,945 ha) yerleşim, \%6.24'ü (8300,54 ha) açık alandır.

Merkez İlçe topraklarının ise yaklaşık \%40'ı (2114.58 ha) tarıma elverişli olup bunun \%17'si (947.23 ha) sera alanı, \%12'si (657.66 ha) örtüalt yetiştircilik alanı, \%9'u (509.69 ha) tarımsal nitelikli açık tarım toprağı oluşturmaktadır. Bu toprakların arazi kullanımı bakımından \%39'u (2119.12 ha) II. sınıf arazi, \%22'si (1198.66 ha.) yerleşim, \%6'sı (329.97 ha) taşkın alanındır (Şekil 6).

Merkez İlçe'de alüvyonlar \%51'lik (761 ha), plaj \%35'lik (520 ha), mermer, şişt ve kırıntılar ise \%14'lük alan kaplamaktadır. Alüvyon (1065 ha) ve Sığırcık (1065 ha) formasyonları görülürken alanın \%72'si alüvyonlardan oluşmaktadır. Yerleşmenin yaklaşık \%80'i verimli alüvyonlardadır, bol miktarda yeraltısuyu taşıdığından yüzeye yakın alanlarda sıvılaşma riski ile yerleşime uygun olmayan arazilerdedir (Şekil 6).

\section{Sonuç ve Öneriler}

Anamur kenti ve çevresindeki mekânsal oluşumun en önemli belirleyicilerinden birisi fizyografik yapıdır. Doğuda Dragon (Anamur) Çayı ve Azı Tepesi, batıda Sultansuyu ve Yalçıdağ, kuzeyde Sazlıtepe, güneyde Akdeniz ve Anamur Ovası eşik oluşturmaktadır.

Hakim rüzgar yönü kışın kuzey (Yıldız) ve kuzeybatı (Karayel), yazın güneybatı (Lodos) yönündedir. Ancak topoğrafyaya bağlı kuzey, doğu ve batıda yüksek dağlık alan, duvar etkisi yaratan Taşeli Platosu ile kuzey ve kuzeybatdan gelen soğuk rüzgarlardan etkilenmemektedir (Sarı ve İnan, 2010). ${ }^{6}$ Doğal yapının ve klimatik etmenlerinin tümü Anamur'u bir tarım kenti olarak var eden, örtüalt sebze-meyve üreticiliği ve seracilık faaliyetlerine yıl boyunca devam ettirebilen mikroklima alanlarını oluşturmaktadır. Ülkemiz muz yetiştiriciliğinin \%53'ü ve muz seralarının \%64'üne sahip Anamur Illçesi'nde açık tarım topraklarında üretimden örtüalt yetiştiriciliği ve seralara geçiş \%89 oranındadır. Açık tarım toprakları hızla ekonomik getirisi yüksek muz seraları ile kaplanmakta ve tarımsal sanayi alanlarına dönüşmektedir.

Merkez İlçe topraklarının \%80'i sera ile kaplı olduğundan yağmur suyu toprakla temas etmemekte, tarımsal verimlilik için yanlış sulama ve gübreleme toprak yapısını bozmakta ve kirletmektedir. Üretim yeteneği (biyolojik performansı) yüksek Alüvyonel ve II. sınıf AKKS topraklarında seracılık faaliyetleri ve yerleşimin yaygınlaşması açık tarım topraklarının yok olmasına neden olmaktadır.

Seraların yönelişlerindeki yanlışlıklar, yüksekliklerindeki (alçak ve yüksek) plansızlıklar güneşlenme, havalandırma ve ulaşım gibi sorunlara neden olmakta, sera tiplerinin çeşitliliği, düzensizliği görüntü kirliliği yaratmaktadır.

i̇lçenin \%80'i Orman Alanı olup hem de VII. sınıf AKKS ve Kireçsiz Kahverengi topraklarda, \%7'si Anamur Ovası'da olup hem II. sınıf AKKS hem de Alüvyonel ve Kollüviyol topraklara sahiptir. Sonuç olarak Merkez İlçe yerleşim alanının

6 Sarı ve İnan, 2010, s. 326-362. 
tamamı tarımsal performansı yüksek alüvyonal topraklar üzerinde yer almıştır.

Anamur İlçesi'nin \%83'ünü orman alanlarından oluşmakta, orman alanlarında bulunan yerleşim alanları \%0.64 (9.57 ha) ile kırsal nitelikli bir yapılaşma şeklindedir. Günümüzde iki vadi oluşumu arasında ve Anamur Ovası üzerinde yer seçen mevcut yerleşmenin, gelecekte topografya kısıtlayıcılığındaki ilerleme yönünün Anamur Çayı boyunca ilçenin kuzeydoğu aksına doğru olması uygun görünmektedir.

Gıda, Tarım ve Hayvancılık Bakanlığı'nın 3/7/2005 tarihli 5403 sayılı Büyükova Kanunu'nun 16. maddesi ve 21/11/2016 tarihli 12636 sayılı yazısına göre Anamur Ovası Büyükova kapsamında değerlendirilecektir. Buna göre ortalama eğimi \%8'den az olan, 10 hektardan büyük planlı alanlar hariç Büyükova sınırları içerisindeki tüm araziler, büyüklüklerine bakılmaksızın Tarımsal siт Alanı statüsündedir. Büyükova sınırları içindeki mevcut yerleşmeler korunmalı, ova içindeki açık araziler tarım dışı amaçla kullanılmamalıdır. Tarım topraklarının bitkisel üretim amacı dışında kullanılmaması, seralar ve tarımsal amaçlı yapıların ova bütünlüğünü korumak için ova sınırı dışında tesisi gereklidir. Ancak Optimal Peyzaj Uygunluk Analizi Yöntemi (LANDEP) ve güncel arazi kullanım haritalarının karşılaştırması sonucunda Anamur Merkez ilıçe' topraklarının mevcut sera yapıları ve örtüalt yetiştiricilik alanlarının \%60' III. sınıf AKKS tarıma en uygun alanlarında yeraldığı, Tarım Deseni Analizi'ne göre \%38'i sera, \%38'i örtüalt yetiştiricilik alanı, \%24'ü tarımsal nitelikli açık tarım toprağı olarak kullanıldığı tespit edilmiştir. Üretim yeteneği tarımsal performansı en yüksek alanlar yerleşim alanı olarak kullanılmakta, ova alanı, vadi tabanı ve taşkın alanlarında, koruma statüsü bakımından da Büyükova ve havza sınırlarında yer almaktadır.

Bu araştırma kapsamında sonuç olarak mevcut yerleşimin gelişimi Büyükova Tarımsal Sit Alanı'na doğru gelişiminin önemli bir tehdit oluşturduğu tespit edilmiştir. Tarımsal yapılarının tesisi ile tarımsal sanayinin henüz işgal etmediği tarımsal nitelikli açık tarım topraklarının ve Büyükova Tarımsal Sit Alanı, Havza Koruma Alanı'nın "Mutlak Tarım Yapılabilir Alanlar" statüsünde tarımsal amaç dışında kullanılmaması gereklidir.

Bununla birlikte araştırma alanının ekstrem iklim koşullarına ilaveten küresel iklim değişikliğiyle sellerde artış, kuraklık, bitkisel ve hayvansal üretimde verimin azalması, orman yangınlarında artış, sulak alanların yok olması, biyolojik çeşitliliğin azalması ve tarım kenti Anamur'u tehdit eden diğer önemli etmenlerdir. Anamur İlçesi "Küresel iklim Değişikliği Eylem Planı" hazırlanmalı ve tarımsal faaliyetlere bağı ılası riskler belirlenmeli ve önlemler alınmalı, doğal kaynakların sürdürülebilirliği sağlanmalıdır.

\section{Kaynaklar}

Akbulak, C. (2010) “Analitik Hiyerarşi Süreci ve Coğrafi Bilgi Sis- temleri ile Yukarı Karamenderes Havzası'nın Arazi Uygunluk Analizi", Uluslararası İnsan Bilimleri Dergisi, Sayı 7(2), s.557576.

Akıncı, H. Yavuz, Ö. A. ve Turgut, B. (2012) "AHP Yöntemi Ile Tarıma Uygun Alanların Belirlenmesi", Zonguldak, IV. Uzaktan Algılama ve Coğrafi Bilgi Sistemleri Sempozyumu (UZAL-CBS), 16-19 Ekim 2012. s.10.

Alkan, Y. Uzun, G. (2016) “Erdemli Kenti Mücavir Alanı İçinde Ekolojik Kapsamlı Alan Kullanımı Üzerine Bir Araştırma", Akademik Ziraat Dergisi, 5(1), s.35-50.

Atabay, S. Ayaşlıgil, T. Batuk, F. Tüzün, G. (2005 a,b,c,d,e) “Doğal Kaynakların Korunması ve Sürdürülebilirliği", Ed.: E. Aysu. EEB Erzurum-Erzincan-Bayburt Bölgesel Gelişme Planı Kitap I-IIIII-IV-V İstanbul, Tayf Matbaacılık, s.9.1-9.10.

Ayaşlıgil, T. (2011) "Sarıyer Örneğinde Ekolojik Mekan Ayrımı" İstanbul Ticaret Üniversitesi Fen Bilimleri Dergisi, 10(20) s.5579.

Ayaşlıgil, T. (2017) "Alan Kullanımı Karar Sürecinde Optimal Uygunluk Analiz Yöntemi", Ed.: Y. Aksoy, Yaşamın Her Karesinde Toprak, Çevre Sorunları ve Çözüm Arayışları, İstanbul, Aydın Üniversitesi Yayını. E-ISBN:978-605-4303-80-9, s.514-531.

Bandyopadhyay, S. Jaiswal, R.K. Hedge, V.S. \& Jayaraman, V. (2009) "Assessment of Land Suitability Potentials for Agriculture Using a Remote Sensing and GIS Based Approach", International Journal of Remote Sensing, Sayı 30(4), s.879-875.

Cengiz, T. Akbulak, C. (2009) "Application Of Analytical Hierarchy Process and Geographic Information Systems in Land-Use Suitability Evaluation: A Case Study of Dümrek Village (Çanakkale, Turkey)", International Journal of Sustainable Development \& World Ecology 16(4), 286-294.

Çağlayan, A. Dağlı, D. (2016) “Analitik Hiyerarşi Süreci ile Optimal Arazi Kullanımının Belirlenmesi", Türk Coğrafya Dergisi, Sayı 66, s.83-92.

Çelikyay, S. Cengiz, S. Görmüş, S. (2015) “Coğrafi Bilgi Sistemleri ile Bartın Ili'nin Arazi Kullanım Uygunluk Analizi", Bartın Üniversitesi Orman Fakültesi Dergisi, Cilt:17, s.76-85.

Demir, M. Demircioğlu, N.Y. Bulut, Y. Yılmaz, S. Özer, S. (2011) "Alan Kullanım Planlamasında Potansiyel Tarım Alanlarının Ölçütlerinin Coğrafi Bilgi Sistemleri (CBS) Yöntemi Ile Belirlenmesi (İspir Örneği)", Iğdır Üniversitesi Fen Bilimleri Enstitüsü Dergisi. Sayı 1(3), s. 77-86.

Dengiz, O. Sarıoğlu, E. (2013) “Arazi Değerlendirme Çalışmalarında Parametrik Bir Yaklaşım Olan Doğrusal Kombinasyon Tekniği", Tarım Bilimleri Dergisi, Sayı 19, s.101-112.

Erbesler Ayaşlıgil, T. (2019) “Mersin Anamur illçesi Örneğinde Peyzaj Mirasının Sürdürülebilirliği /Sustainabilitiy of Landscape Heritage in Mersin Anamur District Example" WOSMUR World Symposium of Multidisipliner Research. DÜMAS. Mersin, 2. International Mersin Symposium. 23-25 Mayıs 2019, s.173-174.

Esen, F. (2016) “Coğrafi Bilgi Sistemleri (CBS) ve Analitik Hiyerarşi Süreci (AHS) İle Bingöl Ovası ve Yakın Çevresinde Optimal Arazi Kullanımının Belirlenmesi", Akademik Sosyal Araştırmalar Dergisi, Sayı 38 (4), s.176-193.

Feizizadeh, B. Blaschke, T. (2013) "Land Suitability Analysis for Tabriz Country, İran: A Mult-Criteria Evaluation Approach Using GIS", Journal of Environmental Planning and Management, Sayı 56(1). s. 1-23.

Kalogirou, S. (2002) "Expert Systems and GIS: An Application of 
Land Suitability Evaluation", Computers, Environment and Urban Systems. 26, 89-112.

Katen, M. (2008) “ísparta Ovası Optimal Alan Kullanım Planlaması Üzerine Bir Araştırma”, Basılmamış Doktora Tezi, Süleyman Demirel Üniversitesi Fen Bilimleri Enstitüsü.

Mansuroğlu, S. Kınıklı, P. Saatçi, B. (2012) “Antalya'da Kentsel Gelişimin Ekolojik Açıdan Değerlendirilmesi ve Sürdürülebilirlik Kapsamında Önerilerin Geliştirilmesi", Ege Üniversitesi Ziraat Fakültesi Dergisi, Sayı 49 (3), s. 255-264.

MÇDP (2015) Mersin İli Çevre Düzeni Planı ve Kent Bütünü Araştıma- Analitik Etüd Çalışmaları Raporu.

MÇŞiM ÇDP (2016) T.C. Mersin Valiliği Çevre ve Şehircilik il Müdürlüğü, Mersin İli 1/100000 Ölçekli Çevre Düzeni Planı ve Araştırma Raporu.

Perveen, M.F. Nagasawa, R. Uddin, M. and Delowar, H.K.M. (2007) “Crop-Land Suitability Analsis Using A Multi-criteria Evaluation \& GIS Approach" 5th International Symposium on Digital Earth (ISDE5), University of California USA, June 5 2007. s.1-8.

Sarı, S. ve İnan, İ. (2010) “Antalya-Anamur Kıyı Bölgesindeki İklim
Farklılıkları”, Marmara Coğrafya Dergisi, Sayı 22, s.325-362. Saykılı, İ. Birdal, A.C. Türk, (2017) "En Uygun Arazi Kullanım Planlarının CBS İle İncelenmesi: Sivas ilii Örneği”, Geomatik Dergisi, Journal of Geomatics, 2(3);126-134.

Sunkar, M. ve Uysal, A. (2014) “Anamur (Dragon) Çayı'nın (Mersin) Hidrografik özellikleri ve Ekonomik Potansiyeli", Coğrafya Dergisi Sayı 28, s.69-93.

Tozar, T. (2006) “Doğal Kaynakların Sürdürülebilirliği İçin GeliştiriIen Ekolojik Planlama Yöntemleri", Basılmamış Yüksek Lisans Tezi, Yıldız Teknik Üniversitesi Fen Bilimleri Enstitüsü.

Wang, F. (1994) "The Use of Artifical Neural Networks in a Geographical Information System for Agricultural Land-Suitability Assessment", Environment and Planning. Sayı 26, s.265-284.

Yeşil, M. Yılmaz, H. (2013) "Tozanlı Havzası Tokat-Almus İlçesi Ekolojik Temelli Kırsal Peyzaj Planlaması", Akademik Ziraat Dergisi Sayı 2(2), s.63-74.

Zengin, M. Yılmaz, S. (2008) “Ardahan Kura Nehri ve Yakın Çevresi Alan Kullanımlarının Belirlemesi ve Optimal Alan Kullanım Önerileri", Atatürk Üniversitesi Ziraat Fakültesi Dergisi, Sayı 39(1), s.43-54. 